\title{
Optimization of medium composition for in vitro shoot proliferation and growth of date palm cv. Mejhoul
}

\author{
Mouaad Amine Mazri $^{1} \cdot$ Reda Meziani $^{2} \cdot$ Jamal El Fadile $^{2} \cdot$ Az-eddine Ezzinbi $^{1}$
}

Received: 3 March 2016/ Accepted: 2 May 2016/Published online: 12 May 2016

(c) The Author(s) 2016. This article is published with open access at Springerlink.com

\begin{abstract}
The effects of major mineral salts, L-glutamine, myo-inositol and carbon source on shoot bud proliferation of date palm (Phoenix dactylifera L.) cv. Mejhoul were evaluated. Different concentrations of ammonium nitrate $\left(\mathrm{NH}_{4} \mathrm{NO}_{3} ; 550,825\right.$ or $\left.1650 \mathrm{mg} / \mathrm{L}\right)$, potassium nitrate $\left(\mathrm{KNO}_{3} ; 633.3,950\right.$ or $\left.1900 \mathrm{mg} / \mathrm{L}\right)$, calcium chloride dehydrate $\left(\mathrm{CaCl}_{2} \cdot 2 \mathrm{H}_{2} \mathrm{O} ; 147,220\right.$ or $\left.440 \mathrm{mg} / \mathrm{L}\right)$, potassium dihydrogen phosphate $\left(\mathrm{KH}_{2} \mathrm{PO}_{4} ; 57,85\right.$ or $\left.170 \mathrm{mg} / \mathrm{L}\right)$, magnesium sulfate heptahydrate $\left(\mathrm{MgSO}_{4} \cdot 7 \mathrm{H}_{2} \mathrm{O} ; 123,185\right.$ or $370 \mathrm{mg} / \mathrm{L})$, L-glutamine and myo-inositol $(0.5,1,1.5$ and $2 \mathrm{~g} / \mathrm{L}$ ), sucrose, sorbitol, mannitol or commercial granulated sugar $(10,20,30,40$ or $50 \mathrm{~g} / \mathrm{L})$ were tested. The highest number of shoot buds per explant (18.7) occurred on the medium containing $825 \mathrm{mg} / \mathrm{L} \mathrm{NH}_{4} \mathrm{NO}_{3}, 1900 \mathrm{mg} / \mathrm{L}$ $\mathrm{KNO}_{3}, \quad 220 \mathrm{mg} / \mathrm{L} \quad \mathrm{CaCl}_{2} \cdot 2 \mathrm{H}_{2} \mathrm{O}, \quad 170 \mathrm{mg} / \mathrm{L} \quad \mathrm{KH}_{2} \mathrm{PO}_{4}$, $370 \mathrm{mg} / \mathrm{L} \mathrm{MgSO}_{4} \cdot 7 \mathrm{H}_{2} \mathrm{O}$ as well as $1 \mathrm{~g} / \mathrm{L}$ L-glutamine, $2 \mathrm{~g} /$ $\mathrm{L}$ myo-inositol and $30 \mathrm{~g} / \mathrm{L}$ sucrose. The results showed that the frequency of hyperhydricity significantly increased in media containing $1650 \mathrm{mg} / \mathrm{L} \mathrm{NH}_{4} \mathrm{NO}_{3}$. The concentrations of L-glutamine, myo-inositol and carbon source significantly affected the number of shoot buds per explant. However, they had no effect on hyperhydricity, tissue browning and precocious rooting. Shoots of $4.5-6.0 \mathrm{~cm}$ in length were isolated and transferred onto hormone-free
\end{abstract}

Mouaad Amine Mazri

m.a.mazri@gmail.com

1 Institut National de la Recherche Agronomique, CRRAMarrakech, UR Agro-Biotechnologie, Laboratoire de Biotechnologie Végétale, Avenue Mohammed 6, B.P. 533, Marrakech, Morocco

2 Institut National de la Recherche Agronomique, CRRAErrachidia, UR Systèmes Oasiens, Laboratoire National de Culture des Tissus du Palmier Dattier, Avenue Moulay Ali Cherif, B.P. 2, Errachidia, Morocco media for elongation and rooting. After 3 months, the developed plantlets were successfully transplanted in a glasshouse and over $90 \%$ survived acclimatization.

Keywords Carbon source · L-Glutamine - Mineral salts · Myo-inositol · Organogenesis · Phoenix dactylifera L.

$\begin{array}{ll}\text { Abbreviations } & \\ \mathrm{CaCl}_{2} \cdot 2 \mathrm{H}_{2} \mathrm{O} & \text { Calcium chloride dehydrate } \\ \mathrm{KH}_{2} \mathrm{PO}_{4} & \text { Potassium dihydrogen phosphate } \\ \mathrm{KNO}_{3} & \text { Potassium nitrate } \\ \mathrm{MgSO}_{4} \cdot 7 \mathrm{H}_{2} \mathrm{O} & \text { Magnesium sulfate heptahydrate } \\ \mathrm{MS} & \text { Murashige and Skoog } \\ \mathrm{NH}_{4} \mathrm{NO}_{3} & \text { Ammonium nitrate } \\ \text { PGR } & \text { Plant growth regulator }\end{array}$

\section{Introduction}

Date palm (Phoenix dactylifera L.) is an agronomically, socioeconomically and ecologically important crop species in the Middle East and North Africa. The worldwide population of date palm trees is estimated to be around 150 million (Al-Khayri et al. 2015). In Morocco, date palm covers 50,000 ha with 5.4 million trees and 453 cultivars (Sedra 2015). Among these cultivars, cv. Mejhoul, also known as Medjool, Medjhool, Medjehuel and Mejhul (Elhoumaizi et al. 2006), is the most sought after and most famous cultivar worldwide (Sedra 2015). Mejhoul is also the most popular and most desired variety by the Moroccan farmers and consumers. Unfortunately, cv. Mejhoul is threatened by bayoud, a very dangerous disease caused by the fungus Fusarium oxysporum f. sp. albedinis, which has 
decimated over 12 million palm trees (Saker 2011), and significantly decreased the population of cv. Mejhoul (Sedra 2011).

To preserve cv. Mejhoul from bayoud and to produce enough plants to satisfy the high demand of farmers and consumers, developing a large-scale propagation system then planting regenerants in bayoud-free areas is the only practical solution. Along this line, a micropropagation program through organogenesis was released in 2010 by the Moroccan Ministry of Agriculture, including cultivars of high fruit quality such as Najda, Boufeggous and Bouskri. The amount of plants of cv. Mejhoul aimed to be produced annually within this program is $67 \%$ of the total amount of plants produced. However, micropropagation of date palm is genotype dependent (Jain 2012), and cv. Mejhoul is one of the most recalcitrant cultivars to in vitro manipulations. Therefore, developing an efficient regeneration system through organogenesis for this cultivar would require a high optimization of media components and culture conditions.

Studies on date palm micropropagation through organogenesis are scarce. In the past few years, regeneration systems through this technique were reported in some cultivars; e.g., cv. Maktoom (Khierallah and Bader 2007), cv. Dhakki (Khan and Bi Bi 2012), cv. Hillawi (Al-Mayahi 2014) and cv. Boufeggous (Mazri 2015). However, the majority of works focused on the effects of plant growth regulators (PGRs). The effects of other factors such as mineral salts, L-glutamine, myo-inositol and carbon source have been scarcely evaluated for date palm organogenesis (Al-Khateeb 2008a; Mazri 2013, 2014; Mazri and Meziani 2013)

Major mineral salts (macronutrients) are inorganic elements needed in relatively large amounts for healthy and vigorous growth of plants (George and de Klerk 2008). Carbohydrates are essential elements for in vitro propagation of plants (Thorpe et al. 2008). They are employed as a source of energy and as an osmotic agent (Thorpe et al. 2008), and to replace the carbon which is normally fixed by plants from the atmosphere by photosynthesis (George and de Klerk 2008). The mineral and carbohydrate requirements for shoot bud proliferation of date palm seem to depend on the genotype used. With regard to L-glutamine and myo-inositol, their effects on date palm organogenesis have never been evaluated. L-Glutamine is an amino acid known for promoting and maintaining cell function (Newsholme et al. 2003). It has been used to promote somatic embryo proliferation, maturation and germination of many plant species, including date palm (Encina et al. 2014; Kim and Moon 2007; Zouine and El Hadrami 2007; Zouine et al. 2005). Myo-inositol is a vitamin that promotes cell and protoplast division (Bellini et al. 1990; Kim et al. 2003; Kiviharju et al. 2005), as well as callus growth (Sepehr and Ghorbanli 2002).
The success of date palm organogenesis is hampered by some physiological disorders: hyperhydricity, a morphological anomaly in which explants are glassy, water soaked and translucent (Debergh et al. 1992); tissue browning, which occurs due to the high levels of caffeoylshikimic acids contained in date palm tissues (Loutfi and El Hadrami 2005); and precocious rooting of organogenic cultures, which decreases bud formation (Al-Khateeb 2008b). The composition of the culture medium affects the incidence of these physiological disorders. Therefore, it is necessary to take into account their occurrence during the optimization of the culture medium.

The purpose of this investigation was to optimize the concentrations of mineral salts, L-glutamine, myo-inositol and carbon source for a rapid and efficient shoot bud multiplication of the recalcitrant date palm cultivar Mejhoul and to examine their effects on the incidence of hyperhydricity, tissue browning and precocious rooting. Accordingly, a total of 70 different culture media were evaluated.

\section{Materials and methods}

\section{Plant material and culture conditions}

This study used organogenic cultures, comprising four buds each, and obtained from shoot tip explants of date palm cv. Mejhoul as described by Beauchesne et al. (1986) with some modifications in the disinfection process. Briefly, offshoots (3-year-old) were removed from adult trees. The outer leaves were detached then the shoot tip was extracted. The shoot tip was subjected to disinfection with $0.03 \%$ solution of potassium permanganate (Sigma, Steinheim, Germany) in commercial liquid bleach (ACE, Industries Marocaines Modernes, Casablanca, Morocco) for 20 min followed by three rinses with sterile distilled water. The explants used for organogenic culture initiation were taken from the meristematic region and then cultured for 9 months on half-strength Murashige and Skoog (1962) medium (MS/2) supplemented with $30 \mathrm{~g} / \mathrm{L}$ sucrose (Sigma, St. Louis, MO, USA), $0.2 \mathrm{~g} / \mathrm{L}$ L-glutamine (Sigma, St. Louis, MO, USA), $0.1 \mathrm{~g} / \mathrm{L}$ myo-inositol (Sigma, St. Louis, MO, USA), 2 g/L polyvinylpyrrolidone (Duchefa Biochemie, Haarlem, The Netherlands), $3 \mathrm{mg} / \mathrm{L}$ 2-naphthoxyacetic acid (NOA), $1 \mathrm{mg} / \mathrm{L}$ 1-naphthaleneacetic acid (NAA), $1 \mathrm{mg} / \mathrm{L}$ indole-3-acetic acid (IAA), $0.1 \mathrm{mg} / \mathrm{L}$ N6-[2-isopentenyl] adenine (2iP) and $6 \mathrm{~g} / \mathrm{L}$ agar (Sigma, St. Louis, MO, USA). The $\mathrm{pH}$ of the culture medium was adjusted to 5.6 before autoclaving at $121{ }^{\circ} \mathrm{C}$ for $25 \mathrm{~min}$ at $103 \mathrm{kPa}$. The explants were maintained in darkness at $25{ }^{\circ} \mathrm{C}$ and transferred to fresh medium every 4 weeks. 
Table 1 Mineral salts, L-glutamine, myo-inositol and carbon source concentrations tested during shoot bud proliferation of date palm cv. Mejhoul

\begin{tabular}{|c|c|c|c|c|c|c|}
\hline \multirow[t]{2}{*}{ Medium component } & \multicolumn{6}{|l|}{ Concentration } \\
\hline & Standard medium & Experiment 1 & Experiment 2 & Experiment 3 & Experiment 4 & Improved medium \\
\hline $\mathrm{NH}_{4} \mathrm{NO}_{3}(\mathrm{mg} / \mathrm{L})$ & 825 & $550-1650^{\mathrm{a}}$ & 825 & 825 & 825 & 825 \\
\hline $\mathrm{KNO}_{3}(\mathrm{mg} / \mathrm{L})$ & 950 & $633.3-1900^{\mathrm{a}}$ & 1900 & 1900 & 1900 & 1900 \\
\hline $\mathrm{CaCl}_{2} \cdot 2 \mathrm{H}_{2} \mathrm{O}(\mathrm{mg} / \mathrm{L})$ & 220 & 220 & $147-440^{\mathrm{a}}$ & 220 & 220 & 220 \\
\hline $\mathrm{MgSO}_{4} \cdot 7 \mathrm{H}_{2} \mathrm{O}(\mathrm{mg} / \mathrm{L})$ & 185 & 185 & $123-370^{\mathrm{a}}$ & 370 & 370 & 370 \\
\hline $\mathrm{KH}_{2} \mathrm{PO}_{4}(\mathrm{mg} / \mathrm{L})$ & 85 & 85 & $57-170^{\mathrm{a}}$ & 170 & 170 & 170 \\
\hline L-Glutamine (g/L) & 0.25 & 0.25 & 0.25 & $0.5-2^{\mathrm{a}}$ & 1 & 1 \\
\hline Myo-inositol (g/L) & 0.25 & 0.25 & 0.25 & $0.5-2^{\mathrm{a}}$ & 2 & 2 \\
\hline Sucrose (g/L) & - & - & - & - & $10-50^{\mathrm{a}}$ & 30 \\
\hline Sorbitol (g/L) & - & - & - & - & $10-50^{\mathrm{a}}$ & - \\
\hline Mannitol (g/L) & - & - & - & - & $10-50^{\mathrm{a}}$ & - \\
\hline Commercial granulated sugar $(\mathrm{g} / \mathrm{L})$ & 30 & 30 & 30 & 30 & $10-50^{\mathrm{a}}$ & - \\
\hline
\end{tabular}

All media were supplemented with vitamins and minor salts of MS basal formulation, $0.2 \mathrm{mg} / \mathrm{L} \mathrm{NOA}, 0.2 \mathrm{mg} / \mathrm{L} \mathrm{IAA}, 0.4 \mathrm{mg} / \mathrm{L} 2 \mathrm{iP}, 0.4 \mathrm{mg} / \mathrm{L}$ kinetin, $1 \mathrm{~g} / \mathrm{L}$ PVP and $6 \mathrm{~g} / \mathrm{L}$ agar

a The concentration range tested in each experiment

During the multiplication phase (experiments 1,2,3 and 4), all media (Table 1) were supplemented with $0.2 \mathrm{mg} / \mathrm{L}$ NOA, $0.2 \mathrm{mg} / \mathrm{L}$ IAA, $0.4 \mathrm{mg} / \mathrm{L} 2 \mathrm{iP}$ and $0.4 \mathrm{mg} / \mathrm{L}$ kinetin as suggested by Meziani et al. (2015). In all experiments, media were supplemented with $1 \mathrm{~g} / \mathrm{L}$ polyvinylpyrrolidone, gelled with $6 \mathrm{~g} / \mathrm{L}$ agar and the $\mathrm{pH}$ was adjusted to 5.7 prior to autoclaving for $25 \mathrm{~min}$ at $121^{\circ} \mathrm{C}$ at $103 \mathrm{kPa}$. For each experiment, two organogenic cultures were placed in a jar $(12 \mathrm{~cm}$ in height, $6.5 \mathrm{~cm}$ in diameter) containing $40 \mathrm{ml}$ of the culture medium and cultured for 3 months. The explants were maintained at $25^{\circ} \mathrm{C}$ in a $16 \mathrm{~h}$ photoperiod with a light intensity of $13.5 \mu \mathrm{mol} \mathrm{m}^{-2} \mathrm{~s}^{-1}$ provided by white cool fluorescent tubes, with transfer to fresh medium every month.

\section{Experimental protocols}

Experiment 1: effects of ammonium nitrate $\left(\mathrm{NH}_{4} \mathrm{NO}_{3}\right)$ and potassium nitrate $\left(\mathrm{KNO}_{3}\right)$ concentrations on shoot bud proliferation

Organogenic cultures of date palm cv. Mejhoul were cultured on media consisting of various concentrations of $\mathrm{NH}_{4} \mathrm{NO}_{3}(550,825$ or $1650 \mathrm{mg} / \mathrm{L})$ and $\mathrm{KNO}_{3}(633.3,950$ or $1900 \mathrm{mg} / \mathrm{L}$ ); as well as $220 \mathrm{mg} / \mathrm{L}$ calcium chloride dehydrate $\left(\mathrm{CaCl}_{2} \cdot 2 \mathrm{H}_{2} \mathrm{O}\right), 185 \mathrm{mg} / \mathrm{L}$ magnesium sulfate heptahydrate $\left(\mathrm{MgSO}_{4} \cdot 7 \mathrm{H}_{2} \mathrm{O}\right), 85 \mathrm{mg} / \mathrm{L}$ potassium dihydrogen phosphate $\left(\mathrm{KH}_{2} \mathrm{PO}_{4}\right), 30 \mathrm{~g} / \mathrm{L}$ commercial granulated sugar (Cosumar, Casablanca, Morocco), $0.25 \mathrm{~g} / \mathrm{L}$ L-glutamine, $0.25 \mathrm{~g} / \mathrm{L}$ myo-inositol, vitamins and minor salts of MS medium.
Experiment 2: effects of $\mathrm{CaCl}_{2} \cdot 2 \mathrm{H}_{2} \mathrm{O}, \mathrm{MgSO}_{4} \cdot 7 \mathrm{H}_{2} \mathrm{O}$ and $\mathrm{KH}_{2} \mathrm{PO}_{4}$ on shoot bud proliferation

Organogenic cultures were cultured for 3 months on media containing $825 \mathrm{mg} / \mathrm{L} \mathrm{NH} \mathrm{NO}_{3}, 1900 \mathrm{mg} / \mathrm{L} \mathrm{KNO}_{3}$ (these concentrations were chosen according to the results from experiment 1), $30 \mathrm{~g} / \mathrm{L}$ commercial granulated sugar, $0.25 \mathrm{~g} / \mathrm{L}$ L-glutamine, $0.25 \mathrm{~g} / \mathrm{L}$ myo-inositol, vitamins and minor salts of MS medium, and supplemented with various concentrations of $\mathrm{CaCl}_{2} \cdot 2 \mathrm{H}_{2} \mathrm{O}(147,220$ or $440 \mathrm{mg} / \mathrm{L})$, $\mathrm{KH}_{2} \mathrm{PO}_{4}(57,85$ or $170 \mathrm{mg} / \mathrm{L})$, and $\mathrm{MgSO}_{4} \cdot 7 \mathrm{H}_{2} \mathrm{O}(123$, 185 or $370 \mathrm{mg} / \mathrm{L}$ ).

\section{Experiment 3: effects of L-glutamine and myo-inositol on shoot bud proliferation}

In this experiment, four concentrations $(0.5,1,1.5$ and $2 \mathrm{~g} / \mathrm{L}$ ) of L-glutamine and myo-inositol were evaluated. L-Glutamine and myo-inositol were supplemented to the culture medium that was containing $825 \mathrm{mg} / \mathrm{L} \mathrm{NH}_{4} \mathrm{NO}_{3}$, $1900 \mathrm{mg} / \mathrm{L} \quad \mathrm{KNO}_{3}, \quad 220 \mathrm{mg} / \mathrm{L} \quad \mathrm{CaCl}_{2} \cdot 2 \mathrm{H}_{2} \mathrm{O}, \quad 170 \mathrm{mg} / \mathrm{L}$ $\mathrm{KH}_{2} \mathrm{PO}_{4}, 370 \mathrm{mg} / \mathrm{L} \mathrm{MgSO} \cdot 7 \mathrm{H}_{2} \mathrm{O}$ (based on the results of experiments 1 and 2), $30 \mathrm{~g} / \mathrm{L}$ commercial granulated sugar, vitamins and minor salts of MS medium.

\section{Experiment 4: effects of carbon source type and concentration on shoot bud proliferation}

According to the results from the above experiments, and to evaluate the effects of carbon sources on shoot bud multiplication, organogenic cultures were cultured on 
media containing $825 \mathrm{mg} / \mathrm{L} \mathrm{NH}_{4} \mathrm{NO}_{3}, 1900 \mathrm{mg} / \mathrm{L} \mathrm{KNO}_{3}$, $220 \mathrm{mg} / \mathrm{L} \quad \mathrm{CaCl}_{2} \cdot 2 \mathrm{H}_{2} \mathrm{O}, 170 \mathrm{mg} / \mathrm{L} \quad \mathrm{KH}_{2} \mathrm{PO}_{4}, 370 \mathrm{mg} / \mathrm{L}$ $\mathrm{MgSO}_{4} \cdot 7 \mathrm{H}_{2} \mathrm{O}, 1 \mathrm{~g} / \mathrm{L}$ L-glutamine, $2 \mathrm{~g} / \mathrm{L}$ myo-inositol, vitamins and minor salts of MS medium, and various concentrations $(10,20,30,40$ or $50 \mathrm{~g} / \mathrm{L})$ of sucrose, sorbitol, mannitol (all purchased from Sigma, St. Louis, MO, USA) or commercial granulated sugar.

\section{Shoot growth and acclimatization}

For shoot elongation and rooting, 4.5-6 cm-long shoots were isolated from the organogenic cultures that were on the medium containing $825 \mathrm{mg} / \mathrm{L} \mathrm{NH} \mathrm{NH}_{3}, 1900 \mathrm{mg} / \mathrm{L}$ $\mathrm{KNO}_{3}, \quad 220 \mathrm{mg} / \mathrm{L} \quad \mathrm{CaCl}_{2} \cdot 2 \mathrm{H}_{2} \mathrm{O}, \quad 170 \mathrm{mg} / \mathrm{L} \quad \mathrm{KH}_{2} \mathrm{PO}_{4}$, $370 \mathrm{mg} / \mathrm{L} \mathrm{MgSO}_{4} \cdot 7 \mathrm{H}_{2} \mathrm{O}, 1 \mathrm{~g} / \mathrm{L}$ L-glutamine, $2 \mathrm{~g} / \mathrm{L}$ myoinositol, $30 \mathrm{~g} / \mathrm{L}$ sucrose, vitamins and minor salts of MS medium as well as PGRs. The shoots were cultured for 3 months on this same medium at $25{ }^{\circ} \mathrm{C}$ and $16 \mathrm{~h}$ photoperiod $\left(40 \mu \mathrm{mol} \mathrm{m} \mathrm{m}^{-2} \mathrm{~s}^{-1}\right)$, but without PGR. After the elongation-rooting phase, well-rooted plantlets with three to four leaves were transferred to the glasshouse as described by Mazri and Meziani (2013). Briefly, the plantlets were removed from the culture medium. The roots were washed in tap water then soaked for $15 \mathrm{~min}$ in a fungicide solution (1 g/L Pelt 44 PM; Bayer CropScience, Bayer Maghreb SA, Casablanca, Morocco). The plantlets were then transferred to plastic bags with a mixture of peat-gravel (1:1) substrate. The bags were placed in a polyethylene tunnel for 2 weeks (98\% relative humidity). After this period, the polyethylene tunnel was gradually opened to adapt plantlets to glasshouse conditions (70\% relative humidity; $27^{\circ} \mathrm{C}$ ).

\section{Data collection and statistical analysis}

During the multiplication phase, there were ten replicates of each treatment, and each replicate consisted of one jar containing two organogenic cultures. After 3 months of
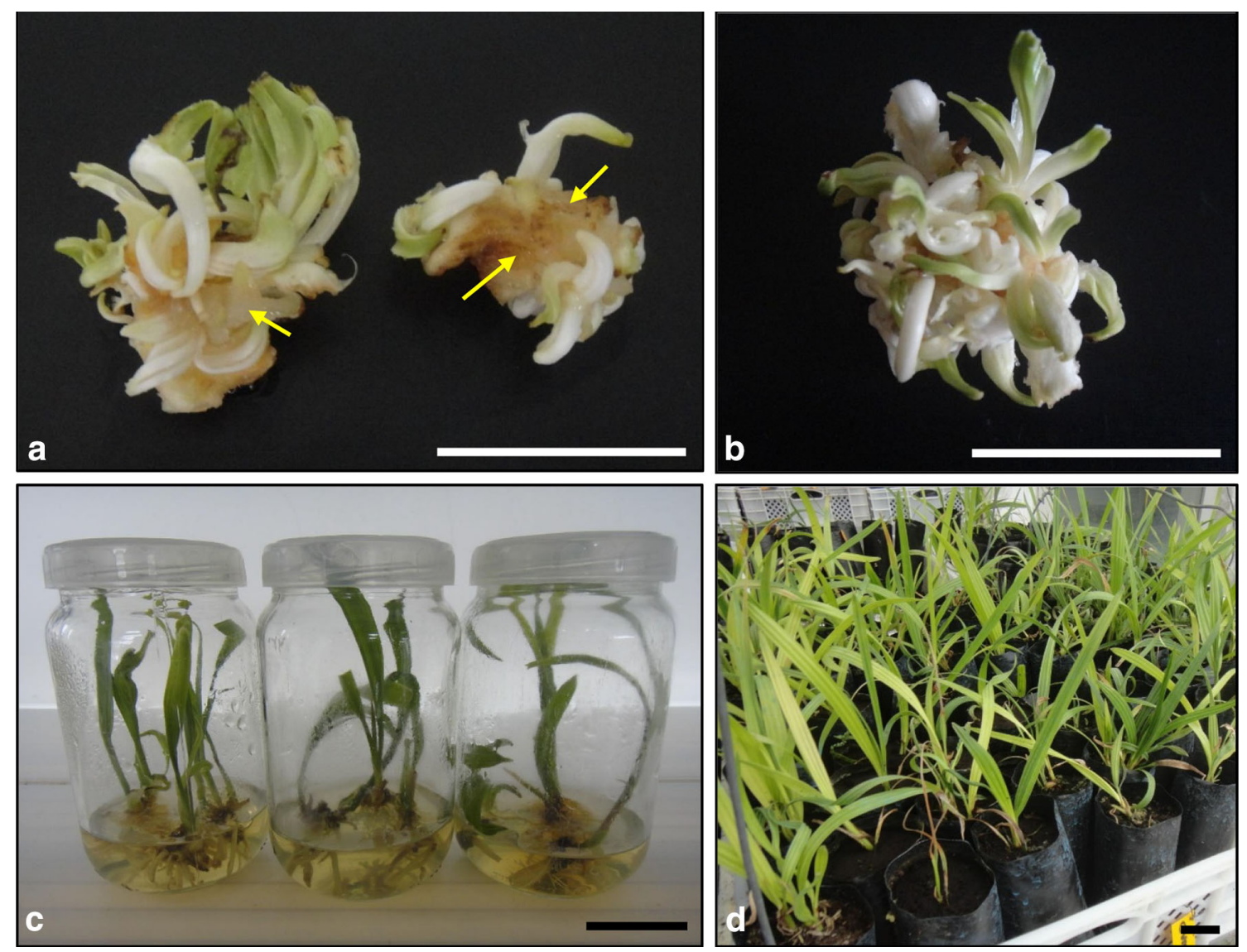

Fig. 1 Shoot bud multiplication, elongation, rooting and acclimatization of date palm (Phoenix dactylifera $\mathrm{L}$.) cv. Mejhoul. a High level of hyperhydricity in organogenic cultures after 1 month of culture on the medium containing $1650 \mathrm{mg} / \mathrm{L} \quad \mathrm{NH}_{4} \mathrm{NO}_{3}, 1900 \mathrm{mg} / \mathrm{L} \quad \mathrm{KNO}_{3}$, $220 \mathrm{mg} / \mathrm{L} \mathrm{CaCl}{ }_{2} \cdot 2 \mathrm{H}_{2} \mathrm{O}, 85 \mathrm{mg} / \mathrm{L} \mathrm{KH}_{2} \mathrm{PO}_{4}, 185 \mathrm{mg} / \mathrm{L} \mathrm{MgSO}{ }_{4} \cdot 7 \mathrm{H}_{2} \mathrm{O}$, $0.25 \mathrm{~g} / \mathrm{L}$ L-glutamine, $0.25 \mathrm{~g} / \mathrm{L}$ myo-inositol, $30 \mathrm{~g} / \mathrm{L}$ commercial granulated sugar, vitamins and minor salts of MS medium. Yellow arrows indicate hyperhydricity. b Organogenic culture after 1 month of culture on the medium containing $825 \mathrm{mg} / \mathrm{L} \mathrm{NH}_{4} \mathrm{NO}_{3}, 1900 \mathrm{mg} / \mathrm{L}$ $\mathrm{KNO}_{3}, \quad 220 \mathrm{mg} / \mathrm{L} \quad \mathrm{CaCl}_{2} \cdot 2 \mathrm{H}_{2} \mathrm{O}, \quad 170 \mathrm{mg} / \mathrm{L} \quad \mathrm{KH}_{2} \mathrm{PO}_{4}, \quad 370 \mathrm{mg} / \mathrm{L}$ $\mathrm{MgSO}_{4} \cdot 7 \mathrm{H}_{2} \mathrm{O}, 1 \mathrm{~g} / \mathrm{L}$ L-glutamine, $2 \mathrm{~g} / \mathrm{L}$ myo-inositol, $30 \mathrm{~g} / \mathrm{L}$ sucrose, vitamins and minor salts of MS medium. c Shoots after 3 months on the PGR-free elongation-rooting medium. d Plantlet survival after 4 months in the glasshouse. Bars correspond to $3 \mathrm{~cm}$ 
culture, the mean number of shoot buds per organogenic culture, the mean number and length of precociously formed roots, the intensity and percentage of hyperhydricity and tissue browning were recorded. During the elongation-rooting phase, the recorded data after 3 months were shoot length $(\mathrm{cm})$ and the mean number and length $(\mathrm{cm})$ of roots. After 4 months in the glasshouse, the percentage of plantlets survival was calculated.

Data were analyzed by ANOVA using a completely randomized design at $5 \%$ significance level, and the comparison of means was performed with the StudentNewman-Keuls test at $P \leq 0.05$ (SPSS v. 16.0, IBM, Chicago, IL, USA). Percentage data were arcsine transformed prior to analysis.

\section{Results}

\section{Experiment 1: effects of $\mathrm{NH}_{4} \mathrm{NO}_{3}$ and $\mathrm{KNO}_{3}$ concentrations on shoot bud proliferation}

Various combinations of $\mathrm{NH}_{4} \mathrm{NO}_{3}$ and $\mathrm{KNO}_{3}$ were evaluated. The maximum capacity for shoot bud formation was

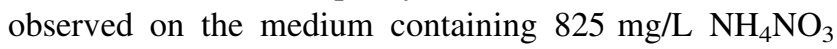
and $1900 \mathrm{mg} / \mathrm{L} \mathrm{KNO}_{3}$, in which the average number of shoot buds per explant was 14.5. The use of $\mathrm{NH}_{4} \mathrm{NO}_{3}$ at the concentration of $1650 \mathrm{mg} / \mathrm{L}$ increased significantly $(P \leq 0.05)$ the incidence of hyperhydricity (Fig. 1a) and decreased the multiplication rate (Table 2). In addition, the buds formed on the medium containing $825 \mathrm{mg} / \mathrm{L} \mathrm{NH}_{4} \mathrm{NO}_{3}$ and $1900 \mathrm{mg} / \mathrm{L} \mathrm{KNO}_{3}$ were thicker and more vigorous. The different concentrations of $\mathrm{NH}_{4} \mathrm{NO}_{3}$ and $\mathrm{KNO}_{3}$ did not affect the frequencies of browning and precocious rooting.

\section{Experiment 2: effects of $\mathrm{CaCl}_{2} \cdot 2 \mathrm{H}_{2} \mathrm{O}, \mathrm{MgSO}_{4} \cdot 7 \mathrm{H}_{2} \mathrm{O}$ and $\mathrm{KH}_{2} \mathrm{PO}_{4}$ on shoot bud proliferation}

After 3 months of culture, the concentrations of $220 \mathrm{mg} / \mathrm{L}$ $\mathrm{CaCl}_{2} \cdot 2 \mathrm{H}_{2} \mathrm{O}, \quad 370 \mathrm{mg} / \mathrm{L} \quad \mathrm{MgSO}_{4} \cdot 7 \mathrm{H}_{2} \mathrm{O}$ and $170 \mathrm{mg} / \mathrm{L}$ $\mathrm{KH}_{2} \mathrm{PO}_{4}$ stimulated shoot bud proliferation, with an average of 15.3 shoot buds per explant (Table 3 ). Lower concentrations of $\mathrm{CaCl}_{2} \cdot 2 \mathrm{H}_{2} \mathrm{O}, \mathrm{MgSO}_{4} \cdot 7 \mathrm{H}_{2} \mathrm{O}$ and $\mathrm{KH}_{2} \mathrm{PO}_{4}$ showed lower multiplication rates, while the concentration of $440 \mathrm{mg} / \mathrm{L}$ of $\mathrm{CaCl}_{2} \cdot 2 \mathrm{H}_{2} \mathrm{O}$ did not increase the number of shoot buds per explant. On the other hand, it has been found that $\mathrm{CaCl}_{2} \cdot 2 \mathrm{H}_{2} \mathrm{O}, \mathrm{MgSO}_{4} \cdot 7 \mathrm{H}_{2} \mathrm{O}$ and $\mathrm{KH}_{2} \mathrm{PO}_{4}$ concentrations do not affect hyperhydricity, tissue browning and precocious rooting of explants.

The findings of the first and second experiments demonstrated that the concentrations of the macro-elements employed do not affect tissue browning and precocious rooting of explants. The concentrations of $825 \mathrm{mg} / \mathrm{L}$ $\mathrm{NH}_{4} \mathrm{NO}_{3}, \quad 1900 \mathrm{mg} / \mathrm{L} \quad \mathrm{KNO}_{3}, \quad 220 \mathrm{mg} / \mathrm{L} \quad \mathrm{CaCl}_{2} \cdot 2 \mathrm{H}_{2} \mathrm{O}$, $370 \mathrm{mg} / \mathrm{L} \mathrm{MgSO}_{4} \cdot 7 \mathrm{H}_{2} \mathrm{O}$ and $170 \mathrm{mg} / \mathrm{L} \mathrm{KK_{2 }} \mathrm{PO}_{4}$ are the most appropriate for shoot bud multiplication of date palm cv. Mejhoul.

\section{Experiment 3: effects of L-glutamine and myo- inositol on shoot bud proliferation}

The combination of $1 \mathrm{~g} / \mathrm{L}$ L-glutamine and $2 \mathrm{~g} / \mathrm{L}$ myoinositol was found to be optimal for shoot bud proliferation. In fact, the average number of shoot buds per explant significantly increased to 17.6 with this combination, with no significant difference $(P>0.05)$ with the combination of $1.5 \mathrm{~g} / \mathrm{L}$ L-glutamine and $2 \mathrm{~g} / \mathrm{L}$ myo-inositol, in which an average of 17.5 shoot buds per explant was obtained

Table 2 Effect of different concentrations of ammonium nitrate $\left(\mathrm{NH}_{4} \mathrm{NO}_{3}\right)$ and potassium nitrate $\left(\mathrm{KNO}_{3}\right)$ on shoot bud proliferation of date palm cv. Mejhoul

\begin{tabular}{|c|c|c|c|c|c|c|c|c|}
\hline $\begin{array}{l}\mathrm{NH}_{4} \mathrm{NO}_{3} \\
(\mathrm{mg} / \mathrm{L})\end{array}$ & $\begin{array}{l}\mathrm{KNO}_{3} \\
(\mathrm{mg} / \mathrm{L})\end{array}$ & $\begin{array}{l}\text { Average number } \\
\text { of shoot buds }\end{array}$ & $\begin{array}{l}\text { Frequency of } \\
\text { hyperhydricity } \\
(\%)\end{array}$ & $\begin{array}{l}\text { Intensity of } \\
\text { hyperhydricity }\end{array}$ & $\begin{array}{l}\text { Frequency of } \\
\text { browning (\%) }\end{array}$ & $\begin{array}{l}\text { Intensity of } \\
\text { browning }\end{array}$ & $\begin{array}{l}\text { Frequency of } \\
\text { precocious rooting } \\
(\%)\end{array}$ & $\begin{array}{l}\text { Average } \\
\text { number of } \\
\text { roots }\end{array}$ \\
\hline 1650 & 1900 & $13.5 \pm 3.4 \mathrm{ab}$ & $65 \pm 33.7 \mathrm{a}$ & ++ & $30 \pm 25.8 \mathrm{a}$ & + & $25 \pm 35.3 \mathrm{a}$ & $1.6 \pm 2.0 \mathrm{a}$ \\
\hline 1650 & 950 & $12.1 \pm 4.1 \mathrm{ab}$ & $65 \pm 41.1 \mathrm{a}$ & ++ & $20 \pm 25.8 \mathrm{a}$ & + & $35 \pm 24.1 \mathrm{a}$ & $1.3 \pm 1.2 \mathrm{a}$ \\
\hline 1650 & 633.3 & $9.8 \pm 3.4 \mathrm{ab}$ & $60 \pm 39.4 a$ & ++ & $20 \pm 34.9 \mathrm{a}$ & + & $35 \pm 41.1 \mathrm{a}$ & $1.2 \pm 1.8 \mathrm{a}$ \\
\hline 825 & 1900 & $14.5 \pm 3.0 \mathrm{a}$ & $25 \pm 35.3 b$ & + & $25 \pm 26.3 \mathrm{a}$ & + & $25 \pm 26.3 a$ & $1.2 \pm 1.5 \mathrm{a}$ \\
\hline $825^{\mathrm{a}}$ & $950^{\mathrm{a}}$ & $12.9 \pm 1.2 \mathrm{ab}$ & $20 \pm 42.1 b$ & + & $30 \pm 34.9 \mathrm{a}$ & + & $30 \pm 25.8 \mathrm{a}$ & $1.1 \pm 1.2 \mathrm{a}$ \\
\hline 825 & 633.3 & $9.1 \pm 5.7 \mathrm{~b}$ & $25 \pm 35.3 b$ & + & $25 \pm 26.3 \mathrm{a}$ & + & $20 \pm 34.9 \mathrm{a}$ & $1.1 \pm 2.0 \mathrm{a}$ \\
\hline 550 & 1900 & $12.4 \pm 3.7 \mathrm{ab}$ & $20 \pm 25.8 b$ & + & $20 \pm 25.8 \mathrm{a}$ & + & $35 \pm 33.7 \mathrm{a}$ & $1.1 \pm 1.1 \mathrm{a}$ \\
\hline 550 & 950 & $9.3 \pm 3.4 b$ & $20 \pm 34.9 b$ & + & $30 \pm 25.8 \mathrm{a}$ & + & $25 \pm 35.3 a$ & $1.2 \pm 1.7 \mathrm{a}$ \\
\hline 550 & 633.3 & $8.9 \pm 3.0 \mathrm{~b}$ & $20 \pm 25.8 b$ & + & $30 \pm 25.8 \mathrm{a}$ & + & $20 \pm 25.8 \mathrm{a}$ & $1.2 \pm 1.6 \mathrm{a}$ \\
\hline
\end{tabular}

Values are mean \pm standard deviation of ten repetitions. Values with the same lowercase letter are not statistically different $(P>0.05)$

Intensities of hyperhydricity, tissue browning and precocious rooting are visually estimated as,+++ and +++ for low, moderate and high, respectively

${ }^{\text {a }}$ The standard concentrations habitually used for shoot bud proliferation 


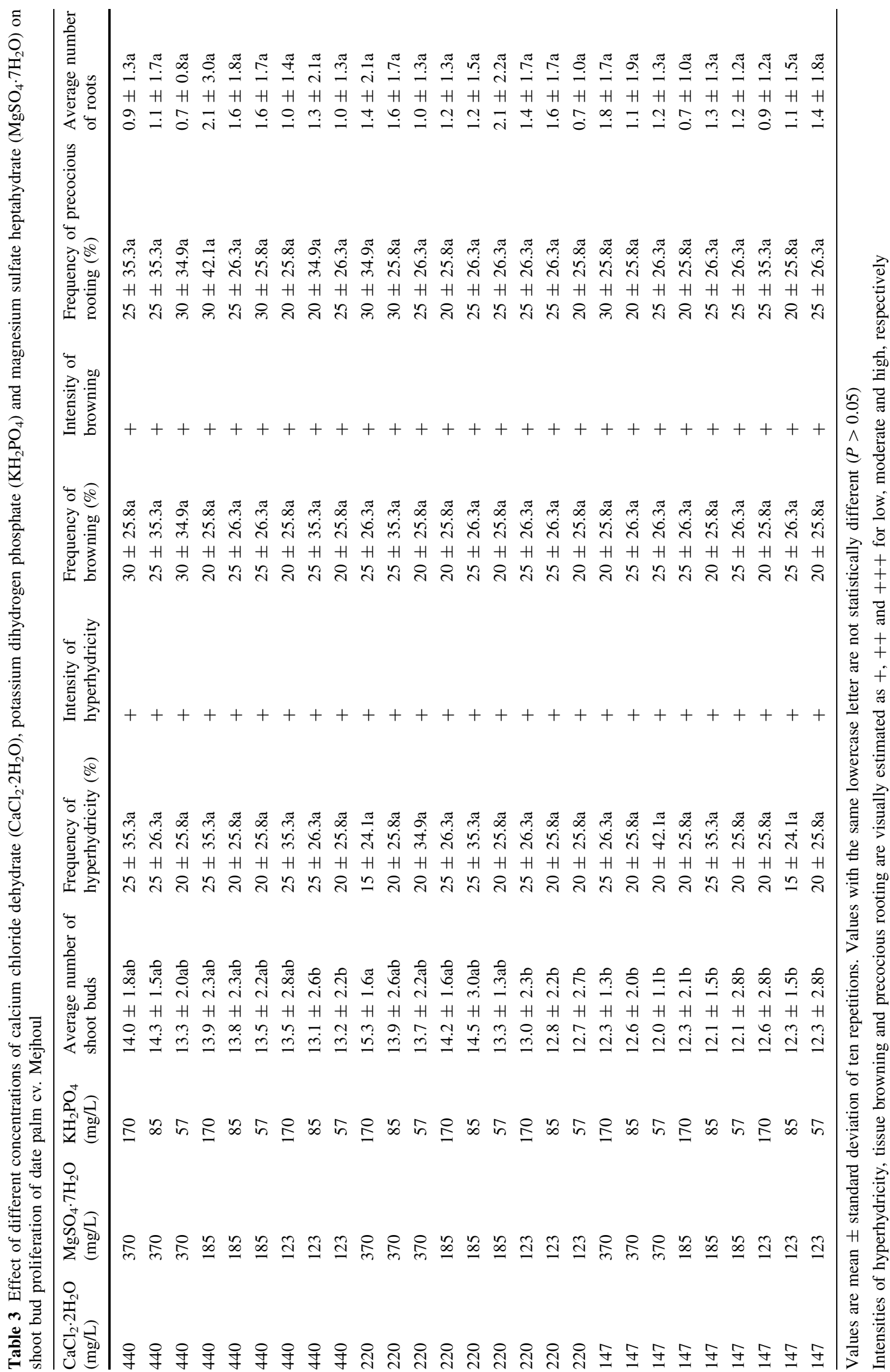


Table 4 Effect of L-glutamine and myo-inositol concentrations on shoot bud proliferation of date palm cv. Mejhoul

\begin{tabular}{|c|c|c|c|c|c|c|c|c|}
\hline $\begin{array}{l}\mathrm{L}- \\
\text { Glutamine } \\
(\mathrm{g} / \mathrm{L})\end{array}$ & $\begin{array}{l}\text { Myo- } \\
\text { inositol } \\
(\mathrm{g} / \mathrm{L})\end{array}$ & $\begin{array}{l}\text { Average number } \\
\text { of shoot buds }\end{array}$ & $\begin{array}{l}\text { Frequency of } \\
\text { hyperhydricity } \\
(\%)\end{array}$ & $\begin{array}{l}\text { Intensity of } \\
\text { hyperhydricity }\end{array}$ & $\begin{array}{l}\text { Frequency of } \\
\text { browning }(\%)\end{array}$ & $\begin{array}{l}\text { Intensity of } \\
\text { browning }\end{array}$ & $\begin{array}{l}\text { Frequency of } \\
\text { precocious rooting } \\
(\%)\end{array}$ & $\begin{array}{l}\text { Average } \\
\text { number of } \\
\text { roots }\end{array}$ \\
\hline 0.5 & 0.5 & $15.4 \pm 2.5 b$ & $20 \pm 25.8 \mathrm{a}$ & + & $25 \pm 35.3 a$ & + & $25 \pm 26.3 a$ & $1.1 \pm 1.4 \mathrm{a}$ \\
\hline 0.5 & 1 & $15.9 \pm 4.7 \mathrm{ab}$ & $25 \pm 42.4 \mathrm{a}$ & + & $25 \pm 26.3 \mathrm{a}$ & + & $30 \pm 42.1 \mathrm{a}$ & $1.6 \pm 2.1 \mathrm{a}$ \\
\hline 0.5 & 1.5 & $15.4 \pm 2.5 b$ & $25 \pm 26.3 \mathrm{a}$ & + & $20 \pm 42.1 \mathrm{a}$ & + & $25 \pm 26.3 \mathrm{a}$ & $1.4 \pm 1.7 \mathrm{a}$ \\
\hline 0.5 & 2 & $16.1 \pm 3.2 \mathrm{ab}$ & $20 \pm 34.9 \mathrm{a}$ & + & $25 \pm 42.4 \mathrm{a}$ & + & $30 \pm 25.8 \mathrm{a}$ & $1.3 \pm 1.5 \mathrm{a}$ \\
\hline 1 & 0.5 & $16.1 \pm 2.9 \mathrm{ab}$ & $25 \pm 26.3 \mathrm{a}$ & + & $20 \pm 34.9 \mathrm{a}$ & + & $20 \pm 25.8 \mathrm{a}$ & $1.0 \pm 1.6 \mathrm{a}$ \\
\hline 1 & 1 & $16.6 \pm 1.8 \mathrm{ab}$ & $25 \pm 42.4 \mathrm{a}$ & + & $20 \pm 25.8 \mathrm{a}$ & + & $20 \pm 42.1 \mathrm{a}$ & $1.1 \pm 2.3 \mathrm{a}$ \\
\hline 1 & 1.5 & $17.1 \pm 3.2 \mathrm{ab}$ & $20 \pm 42.1 \mathrm{a}$ & + & $25 \pm 26.3 \mathrm{a}$ & + & $30 \pm 25.8 \mathrm{a}$ & $1.8 \pm 2.4 \mathrm{a}$ \\
\hline 1 & 2 & $17.6 \pm 3.4 \mathrm{a}$ & $20 \pm 25.8 \mathrm{a}$ & + & $20 \pm 25.8 \mathrm{a}$ & + & $20 \pm 34.9 \mathrm{a}$ & $1.1 \pm 1.9 \mathrm{a}$ \\
\hline 1.5 & 0.5 & $15.5 \pm 2.7 b$ & $20 \pm 25.8 \mathrm{a}$ & + & $25 \pm 42.4 \mathrm{a}$ & + & $25 \pm 35.3 \mathrm{a}$ & $1.1 \pm 1.5 \mathrm{a}$ \\
\hline 1.5 & 1 & $16.0 \pm 3.1 \mathrm{ab}$ & $25 \pm 42.4 \mathrm{a}$ & + & $20 \pm 42.1 \mathrm{a}$ & + & $20 \pm 25.8 \mathrm{a}$ & $1.2 \pm 1.6 \mathrm{a}$ \\
\hline 1.5 & 1.5 & $16.9 \pm 4.9 \mathrm{ab}$ & $25 \pm 35.3 \mathrm{a}$ & + & $25 \pm 35.3 a$ & + & $20 \pm 34.9 \mathrm{a}$ & $1.4 \pm 2.3 \mathrm{a}$ \\
\hline 1.5 & 2 & $17.5 \pm 3.6 \mathrm{a}$ & $20 \pm 34.9 \mathrm{a}$ & + & $20 \pm 42.1 \mathrm{a}$ & + & $25 \pm 35.3 a$ & $1.3 \pm 1.7 \mathrm{a}$ \\
\hline 2 & 0.5 & $16.2 \pm 3.3 \mathrm{ab}$ & $25 \pm 35.3 \mathrm{a}$ & + & $25 \pm 42.4 \mathrm{a}$ & + & $25 \pm 42.4 \mathrm{a}$ & $1.2 \pm 2.1 \mathrm{a}$ \\
\hline 2 & 1 & $16.8 \pm 3.0 \mathrm{ab}$ & $25 \pm 26.3 \mathrm{a}$ & + & $25 \pm 35.3 a$ & + & $25 \pm 35.3 a$ & $1.4 \pm 2.2 \mathrm{a}$ \\
\hline 2 & 1.5 & $17.1 \pm 2.6 \mathrm{ab}$ & $20 \pm 25.8 \mathrm{a}$ & + & $20 \pm 25.8 \mathrm{a}$ & + & $25 \pm 42.4 \mathrm{a}$ & $1.3 \pm 2.1 \mathrm{a}$ \\
\hline 2 & 2 & $17.2 \pm 3.8 \mathrm{ab}$ & $25 \pm 35.3 \mathrm{a}$ & + & $30 \pm 42.1 \mathrm{a}$ & + & $20 \pm 34.9 \mathrm{a}$ & $1.5 \pm 2.4 \mathrm{a}$ \\
\hline
\end{tabular}

Values are mean \pm standard deviation of ten repetitions. Values with the same lowercase letter are not statistically different $(P>0.05)$ Intensities of hyperhydricity, tissue browning and precocious rooting are visually estimated as,+++ and +++ for low, moderate and high, respectively

(Table 4). The different concentrations of L-glutamine and myo-inositol did not show a significant effect on the incidence of hyperhydricity, tissue browning and precocious rooting.

\section{Experiment 4: effects of carbon source type and concentration on shoot bud proliferation}

After 3 months of culture, an average of 18.7 shoot buds per explant was obtained on the medium supplemented with $30 \mathrm{~g} / \mathrm{L}$ sucrose. The use of sorbitol, mannitol and commercial granulated sugar at the same concentration showed lower multiplication rates (17.6-17.9 shoot buds per explant; Table 5). Higher sucrose concentrations did not increase the number of shoot buds, while lower concentrations produced lower number of shoot buds per explant (13.9-17.1). The buds produced on media supplemented with sucrose (Fig. 1b) were morphologically superior to those obtained on media supplemented with sorbitol, mannitol and commercial granulated sugar.

\section{Comparison of standard and improved media}

The final improved medium for shoot bud multiplication of date palm cv. Mejhoul contained $825 \mathrm{mg} / \mathrm{L} \mathrm{NH}_{4} \mathrm{NO}_{3}$, $1900 \mathrm{mg} / \mathrm{L} \quad \mathrm{KNO}_{3}, 220 \mathrm{mg} / \mathrm{L} \quad \mathrm{CaCl}_{2} \cdot 2 \mathrm{H}_{2} \mathrm{O}, \quad 170 \mathrm{mg} / \mathrm{L}$ $\mathrm{KH}_{2} \mathrm{PO}_{4}, 370 \mathrm{mg} / \mathrm{L} \mathrm{MgSO}{ }_{4} \cdot 7 \mathrm{H}_{2} \mathrm{O}, 1 \mathrm{~g} / \mathrm{L}$ L-glutamine, $2 \mathrm{~g} /$
$\mathrm{L}$ myo-inositol and $30 \mathrm{~g} / \mathrm{L}$ sucrose. The average number of shoot buds produced in the improved medium was 18.7, while it was 12.9 in the standard medium (Table 6). The difference was statistically significant $(P<0.05)$ and the increase gained was $44.96 \%$.

\section{Shoot growth, rooting and acclimatization}

Shoot elongation and rooting (Fig. 1c) were achieved on a PGR-free medium consisting of $825 \mathrm{mg} / \mathrm{L} \quad \mathrm{NH}_{4} \mathrm{NO}_{3}$, $1900 \mathrm{mg} / \mathrm{L} \quad \mathrm{KNO}_{3}, 220 \mathrm{mg} / \mathrm{L} \quad \mathrm{CaCl}_{2} \cdot 2 \mathrm{H}_{2} \mathrm{O}, \quad 170 \mathrm{mg} / \mathrm{L}$ $\mathrm{KH}_{2} \mathrm{PO}_{4}, 370 \mathrm{mg} / \mathrm{L} \mathrm{MgSO} \cdot 7 \mathrm{H}_{2} \mathrm{O}, 1 \mathrm{~g} / \mathrm{L}$ L-glutamine, $2 \mathrm{~g} /$ $\mathrm{L}$ myo-inositol and $30 \mathrm{~g} / \mathrm{L}$ sucrose. After 3 months of culture, the average length of shoots was $13.9 \mathrm{~cm}$, the average number of roots per shoot was 4.3 while root length was $4.2 \mathrm{~cm}$, and an interesting survival rate of plantlets of $90 \%$ was obtained after 4 months in the glasshouse (Fig. 1d).

\section{Discussion}

In date palm, Mejhoul is one of the most recalcitrant cultivars in tissue culture. In view of developing an efficient regeneration protocol for this cultivar, the most appropriate nutritional requirements for shoot bud multiplication were determined. The concentration of mineral salts strongly 
Table 5 Effect of carbon source type and concentration on shoot bud proliferation of date palm cv. Mejhoul

\begin{tabular}{|c|c|c|c|c|c|c|c|c|c|c|}
\hline \multicolumn{4}{|c|}{$\begin{array}{l}\text { Carbon source type and concentration } \\
(\mathrm{g} / \mathrm{L})\end{array}$} & \multirow[t]{2}{*}{$\begin{array}{l}\text { Average number } \\
\text { of shoot buds }\end{array}$} & \multirow{2}{*}{$\begin{array}{l}\text { Frequency of } \\
\text { hyperhydricity } \\
(\%)\end{array}$} & \multirow[t]{2}{*}{$\begin{array}{l}\text { Intensity of } \\
\text { hyperhydricity }\end{array}$} & \multirow{2}{*}{$\begin{array}{l}\text { Frequency } \\
\text { of } \\
\text { browning } \\
(\%)\end{array}$} & \multirow{2}{*}{$\begin{array}{l}\text { Intensity } \\
\text { of } \\
\text { browning }\end{array}$} & \multirow{2}{*}{$\begin{array}{l}\text { Frequency } \\
\text { of } \\
\text { precocious } \\
\text { rooting (\%) }\end{array}$} & \multirow{2}{*}{$\begin{array}{l}\text { Average } \\
\text { number of } \\
\text { roots }\end{array}$} \\
\hline Sucrose & Sorbitol & Mannitol & $\begin{array}{l}\text { Commercial } \\
\text { granulated } \\
\text { sugar }\end{array}$ & & & & & & & \\
\hline 10 & - & - & - & $13.9 \pm 1.5 \mathrm{bcde}$ & $20 \pm 25.8 \mathrm{a}$ & + & $20 \pm 25.8 \mathrm{a}$ & + & $20 \pm 25.8 \mathrm{a}$ & $0.6 \pm 0.8 \mathrm{a}$ \\
\hline 20 & - & - & - & $17.1 \pm 2.6 \mathrm{abcd}$ & $20 \pm 25.8 \mathrm{a}$ & + & $20 \pm 25.8 \mathrm{a}$ & + & $20 \pm 25.8 \mathrm{a}$ & $0.8 \pm 1.0 \mathrm{a}$ \\
\hline 30 & - & - & - & $18.7 \pm 3.5 \mathrm{a}$ & $20 \pm 25.8 \mathrm{a}$ & + & $20 \pm 25.8 \mathrm{a}$ & + & $25 \pm 35.3 \mathrm{a}$ & $1.1 \pm 1.5 \mathrm{a}$ \\
\hline 40 & - & - & - & $18.4 \pm 2.8 \mathrm{a}$ & $30 \pm 34.9 \mathrm{a}$ & ++ & $25 \pm 35.3 \mathrm{a}$ & + & $30 \pm 34.9 \mathrm{a}$ & $1.5 \pm 1.6 \mathrm{a}$ \\
\hline 50 & - & - & - & $18.6 \pm 1.8 \mathrm{a}$ & $30 \pm 34.9 \mathrm{a}$ & ++ & $30 \pm 34.9 \mathrm{a}$ & + & $25 \pm 35.3 \mathrm{a}$ & $1.3 \pm 1.7 \mathrm{a}$ \\
\hline- & 10 & - & - & $13.7 \pm 2.0 \mathrm{cde}$ & $20 \pm 25.8 \mathrm{a}$ & + & $20 \pm 25.8 \mathrm{a}$ & + & $20 \pm 25.8 \mathrm{a}$ & $1.2 \pm 1.7 \mathrm{a}$ \\
\hline- & 20 & - & - & $16.9 \pm 3.4 \mathrm{abcd}$ & $20 \pm 25.8 \mathrm{a}$ & + & $25 \pm 26.3 \mathrm{a}$ & + & $20 \pm 25.8 \mathrm{a}$ & $0.7 \pm 0.9 \mathrm{a}$ \\
\hline- & 30 & - & - & $17.9 \pm 2.0 \mathrm{ab}$ & $25 \pm 35.3 a$ & + & $20 \pm 25.8 \mathrm{a}$ & + & $20 \pm 25.8 \mathrm{a}$ & $1.0 \pm 1.3 \mathrm{a}$ \\
\hline- & 40 & - & - & $18.0 \pm 2.8 \mathrm{ab}$ & $30 \pm 25.8 \mathrm{a}$ & ++ & $25 \pm 26.3 \mathrm{a}$ & + & $25 \pm 26.3 \mathrm{a}$ & $1.1 \pm 1.2 \mathrm{a}$ \\
\hline- & 50 & - & - & $17.3 \pm 1.8 \mathrm{abc}$ & $30 \pm 34.9 \mathrm{a}$ & ++ & $30 \pm 34.9 a$ & + & $30 \pm 34.9 \mathrm{a}$ & $1.2 \pm 1.3 \mathrm{a}$ \\
\hline- & - & 10 & - & $13.4 \pm 2.7 \mathrm{de}$ & $20 \pm 25.8 \mathrm{a}$ & + & $20 \pm 25.8 \mathrm{a}$ & + & $15 \pm 24.1 \mathrm{a}$ & $1.2 \pm 1.9 \mathrm{a}$ \\
\hline- & - & 20 & - & $16.3 \pm 2.7 \mathrm{abcde}$ & $25 \pm 26.3 \mathrm{a}$ & + & $25 \pm 35.3 \mathrm{a}$ & + & $20 \pm 25.8 \mathrm{a}$ & $1.2 \pm 1.6 \mathrm{a}$ \\
\hline- & - & 30 & - & $17.8 \pm 3.5 \mathrm{abc}$ & $20 \pm 25.8 \mathrm{a}$ & + & $25 \pm 35.3 \mathrm{a}$ & + & $25 \pm 35.3 \mathrm{a}$ & $1.4 \pm 1.9 \mathrm{a}$ \\
\hline- & - & 40 & - & $17.8 \pm 3.1 \mathrm{abc}$ & $30 \pm 34.9 \mathrm{a}$ & + & $30 \pm 34.9 \mathrm{a}$ & + & $30 \pm 25.8 \mathrm{a}$ & $2.4 \pm 2.1 \mathrm{a}$ \\
\hline- & - & 50 & - & $17.6 \pm 2.5 \mathrm{abc}$ & $30 \pm 25.8 \mathrm{a}$ & ++ & $30 \pm 25.8 \mathrm{a}$ & + & $20 \pm 25.8 \mathrm{a}$ & $1.2 \pm 1.6 \mathrm{a}$ \\
\hline- & - & - & 10 & $13.1 \pm 2.1 \mathrm{e}$ & $25 \pm 35.3 a$ & + & $30 \pm 42.1 \mathrm{a}$ & + & $15 \pm 24.1 \mathrm{a}$ & $0.8 \pm 1.4 \mathrm{a}$ \\
\hline- & - & - & 20 & $16.2 \pm 3.0 \mathrm{abcde}$ & $20 \pm 25.8 \mathrm{a}$ & + & $20 \pm 34.9 \mathrm{a}$ & + & $25 \pm 26.3 \mathrm{a}$ & $1.5 \pm 1.9 \mathrm{a}$ \\
\hline- & - & - & 30 & $17.6 \pm 3.4 a b c$ & $20 \pm 25.8 \mathrm{a}$ & + & $20 \pm 25.8 \mathrm{a}$ & + & $20 \pm 34.9 \mathrm{a}$ & $1.1 \pm 1.9 \mathrm{a}$ \\
\hline- & - & - & 40 & $17.1 \pm 2.5 \mathrm{abcd}$ & $25 \pm 26.3 a$ & + & $30 \pm 34.9 \mathrm{a}$ & + & $30 \pm 34.9 \mathrm{a}$ & $1.8 \pm 2.0 \mathrm{a}$ \\
\hline - & - & - & 50 & $17.4 \pm 2.5 \mathrm{abc}$ & $25 \pm 35.3 \mathrm{a}$ & + & $30 \pm 42.1 \mathrm{a}$ & + & $25 \pm 26.3 \mathrm{a}$ & $2.0 \pm 2.1 \mathrm{a}$ \\
\hline
\end{tabular}

Values are mean \pm standard deviation of ten repetitions. Values with the same lowercase letter are not statistically different $(P>0.05)$

Intensities of hyperhydricity, tissue browning and precocious rooting are visually estimated as,+++ and +++ for low, moderate and high, respectively

Table 6 Comparison of shoot bud proliferation of date palm cv. Mejhoul when grown in standard and improved culture media

\begin{tabular}{|c|c|c|c|c|c|c|c|}
\hline & $\begin{array}{l}\text { Average number } \\
\text { of shoot buds }\end{array}$ & $\begin{array}{l}\text { Frequency of } \\
\text { hyperhydricity (\%) }\end{array}$ & $\begin{array}{l}\text { Intensity of } \\
\text { hyperhydricity }\end{array}$ & $\begin{array}{l}\text { Frequency of } \\
\text { browning (\%) }\end{array}$ & $\begin{array}{l}\text { Intensity of } \\
\text { browning }\end{array}$ & $\begin{array}{l}\text { Frequency of } \\
\text { precocious rooting } \\
(\%)\end{array}$ & $\begin{array}{l}\text { Average } \\
\text { number of } \\
\text { roots }\end{array}$ \\
\hline $\begin{array}{l}\text { Standard } \\
\text { medium }\end{array}$ & $12.9 \pm 1.2 \mathrm{a}$ & $20 \pm 42.1 \mathrm{a}$ & + & $30 \pm 34.9 \mathrm{a}$ & + & $30 \pm 25.8 \mathrm{a}$ & $1.1 \pm 1.2 \mathrm{a}$ \\
\hline $\begin{array}{l}\text { Improved } \\
\text { medium }\end{array}$ & $18.7 \pm 3.5 b$ & $20 \pm 25.8 \mathrm{a}$ & + & $20 \pm 25.8 \mathrm{a}$ & + & $25 \pm 35.3 \mathrm{a}$ & $1.1 \pm 1.5 \mathrm{a}$ \\
\hline
\end{tabular}

Values are mean \pm standard deviation of ten repetitions. Values with the same lowercase letter are not statistically different $(P>0.05)$

Intensities of hyperhydricity, tissue browning and precocious rooting are visually estimated as,+++ and +++ for low, moderate and high, respectively

affected shoot bud multiplication of date palm cv. Mejhoul. Similar results have been observed in other plant species such as Rubus idaeus L. (Poothonga and Reed 2014), Billbergia zebrina (Martins et al. 2015) and some Pyrus genotypes (Reed et al. 2013). Mineral requirements for date palm-cultured tissue seem to vary among cultivars (Mazri and Meziani 2015). Generally, MS and MS/2 basal formulations have been widely used for date palm shoot bud multiplication. For example, in date palm cvs. Maktoom, Dhakki and Hillawi, MS medium was used (Khierallah and Bader 2007; Khan and Bi Bi 2012; Al-Mayahi 2014), while Mazri 2015 used MS/2 medium for cv. Boufeggous. In a previous study on cv. Najda, the effect of six basal formulations was evaluated and it has been found that MS/2 medium is the most appropriate for shoot bud multiplication (Mazri and Meziani 2013). In cv. 16-bis, MS 
medium showed higher multiplication efficiency than woody plant medium and Nitsch medium (Mazri 2013). In the present work, the combination of $825 \mathrm{mg} / \mathrm{L} \mathrm{NH}_{4} \mathrm{NO}_{3}$, $1900 \mathrm{mg} / \mathrm{L} \quad \mathrm{KNO}_{3}, 220 \mathrm{mg} / \mathrm{L} \quad \mathrm{CaCl}_{2} \cdot 2 \mathrm{H}_{2} \mathrm{O}, \quad 170 \mathrm{mg} / \mathrm{L}$ $\mathrm{KH}_{2} \mathrm{PO}_{4}$ and $370 \mathrm{mg} / \mathrm{L} \mathrm{MgSO}_{4} \cdot 7 \mathrm{H}_{2} \mathrm{O}$ considerably stimulated the formation of adventitious buds. It has been found also that hyperhydricity has increased at high concentrations of $\mathrm{NH}_{4} \mathrm{NO}_{3}$ in the medium. This confirms previous statements by Al-Khateeb (2008b) and Abahmane (2011) who reported that high levels of ammonium ions increase the incidence of hyperhydricity. On the other hand, the different levels of mineral salts evaluated did not affect the incidence of tissue browning and precocious rooting.

The addition of L-glutamine and myo-inositol at the concentrations of 1 and $2 \mathrm{~g} / \mathrm{L}$, respectively, significantly enhanced the proliferation of adventitious buds. L-Glutamine is an amino acid known for promoting and maintaining cell function (Newsholme et al. 2003). It is involved in animal cell division (Diestel et al. 2007) and is known to have anti-inflammatory properties (Jain and Khanna 1981), induce weight loss in overweight and obese human adults (Zambom de Souza et al. 2015) and facilitate genetic transformation of some plant species (Kumar et al. 2013). With regard to micropropagation, L-glutamine has been used to stimulate somatic embryo maturation and germination of many plant species such as Picea mariana (Khlifi and Tremblay 1995), Pinus strobus (Garin et al. 2000), Larix leptolepis (Kim and Moon 2007) and Persea americana (Encina et al. 2014). In date palm tissue culture, studies on the effects of L-glutamine are scarce. Zouine et al. (2005) and Zouine and El Hadrami (2007) reported that L-glutamine improves the proliferation of somatic embryos of cvs. Jihel and Bousthami Noir. The results of the present study indicate that L-glutamine improves also the proliferation of date palm shoot buds. In fact, increasing the concentration of L-glutamine to $1 \mathrm{~g} / \mathrm{L}$ significantly increased the number of shoot buds per explant.

Myo-inositol is a vitamin that stimulates cell division and an osmotic stabilizer for sustaining cell division (Kim et al. 2003; Kiviharju et al. 2005). Myo-inositol has been used to promote callus growth (Sepehr and Ghorbanli 2002) and protoplast division (Bellini et al. 1990). To date, the effect of myo-inositol on date palm micropropagation has not been investigated. Interestingly, it has been found that myo-inositol promotes shoot bud proliferation of date palm cv. Mejhoul.

With regard to carbon source type and concentration, it has been found that $30 \mathrm{~g} / \mathrm{L}$ sucrose is the most appropriate for shoot bud multiplication. Lower or higher concentrations of sucrose did not improve shoot bud proliferation. This confirms the findings of Taha et al. (2001), who found that $30 \mathrm{~g} / \mathrm{L}$ sucrose is more effective than 10,20 or $40 \mathrm{~g} / \mathrm{L}$ for the multiplication of shoot buds of date palm $\mathrm{cv}$.
Zaghlool. However, in date palm cv. 16-bis, it has been found that the concentration of $20 \mathrm{~g} / \mathrm{L}$ sucrose is the most appropriate for shoot bud multiplication (Mazri 2014). In cv. Khanezi, sugar type (sucrose, glucose, fructose and maltose) did not show a significant difference in bud formation; however, the concentrations of 30 and $60 \mathrm{~g} / \mathrm{L}$ were the most appropriate in comparison with higher concentrations (Al-Khateeb 2008a). This shows that sugar requirement may differ among genotypes. In the present study, sorbitol, mannitol and commercial granulated sugar appeared to be less effective than sucrose in proliferating shoot buds of date palm cv. Mejhoul. This might be due to the different nutritional and osmotic potentials of these carbon sources, and their different effects on cell growth, differentiation and morphogenesis (Neto and Otoni 2003; Yaseen et al. 2013).

Shoot elongation and rooting were achieved on PGRfree medium as it was previously reported in other date palm cultivars (Mazri 2014, 2015). In fact, it has been found that shoot elongation and rooting on PGR-free media significantly increases the survival rate during the acclimatization phase (Mazri and Meziani 2013). In the present study, the survival rate observed after acclimatization was $90 \%$. Generally speaking, high survival rates were reported in date palm organogenesis (Khan and $\mathrm{Bi} \mathrm{Bi}$ 2012; Khierallah and Bader 2007; Mazri 2015; Meziani et al. 2015).

In conclusion, mineral salts, L-glutamine, myo-inositol, as well as carbon source type and concentration significantly affect shoot bud proliferation of date palm cv. Mejhoul. The optimized culture medium will be useful for the rapid and large-scale propagation of this recalcitrant and endangered date palm cultivar. The effect of some natural compounds is currently being investigated to reduce tissue browning during the initiation and multiplication of adventitious buds of cv. Mejhoul.

\section{Compliance with ethical standards}

Conflict of interest The authors declare that they have no conflict of interest.

Open Access This article is distributed under the terms of the Creative Commons Attribution 4.0 International License (http:// creativecommons.org/licenses/by/4.0/), which permits unrestricted use, distribution, and reproduction in any medium, provided you give appropriate credit to the original author(s) and the source, provide a link to the Creative Commons license, and indicate if changes were made.

\section{References}

Abahmane L (2011) Date palm micropropagation via organogenesis. In: Jain SM, Al-Khayri JM, Johnson DV (eds) Date palm biotechnology. Springer, Dordrecht, pp 69-90 
Al-Khateeb AA (2008a) Regulation of in vitro bud formation of date palm (Phoenix dactylifera L.) cv. Khanezi by different carbon sources. Biores Technol 99:6550-6555

Al-Khateeb AA (2008b) The problems facing the use of tissue culture technique in date palm (Phoenix dactylifera L.). Sci J King Faisal Univ 9:85-104

Al-Khayri JM, Jain SM, Johnson DV (2015) Preface. In: Al-Khayri JM, Jain SM, Johnson DV (eds) Date palm genetic resources and utilization. Springer, Dordrecht, pp v-vi

Al-Mayahi AMW (2014) Thidiazuron-induced in vitro bud organogenesis of the date palm (Phoenix dactylifera L.) cv. Hillawi. Afr J Biotechnol 13:3581-3590

Beauchesne G, Zaid A, Rhiss A (1986) Meristematic potentialities of bottom of young leaves to rapidly propagate date palm. Proceedings second symposium on date palm. King Faisal University, Saudi Arabia, pp 87-94

Bellini C, Chupeau M, Gervais M, Vastra G, Chupeau Y (1990) Importance of myo-inositol, calcium, and ammonium for the viability and division of tomato (Lycopersicon esculentum) protoplasts. Plant Cell Tissue Org Cult 23:27-37

Debergh P, Aitken-Chistie J, Cohen D, Grout B, Von Arnold S, Zimmermann TW, Ziv M (1992) Reconsideration of the term vitrification as used in micropropagation. Plant Cell Tissue Org Cult 30:135-140

Diestel CF, Marques RG, Lopes-Paulo F, Paiva D, Horst NL, Caetano CER, Portela MC (2007) Role of L-glutamine and glycine supplementation on irradiated colonic wall. Int J Colorectal Dis 22:1523-1529

Elhoumaizi MA, Devanand PS, Fang J, Chao CT (2006) Confirmation of 'Medjool' date as a landrace variety through genetic analysis of 'Medjool' accessions in Morocco. J Am Soc Hort Sci 131:403-407

Encina CL, Parisi A, O'Brien C, Mitter N (2014) Enhancing somatic embryogenesis in avocado (Persea americana Mill.) using a two-step culture system and including glutamine in the culture medium. Sci Hortic 165:44-50

Garin E, Bernier-Cardou M, Isabel N, Klimaszewska K, Plourde A (2000) Effect of sugars, amino acids, and culture technique on maturation of somatic embryos of Pinus strobus on medium with two gellan gum concentrations. Plant Cell Tissue Org Cult 62:27-37

George EF, De Klerk GJ (2008) The components of plant tissue culture media I: macro- and micro-nutrients. In: George EF, Hall MA, De Klerk GJ (eds) Plant propagation by tissue culture, 3rd edn. Springer, The Netherlands, pp 65-113

Jain SM (2012) Date palm biotechnology: current status and prospective-an overview. Emir J Food Agric 24(5):386-399

Jain P, Khanna NK (1981) Evaluation of anti-inflammatory and analgesic properties of L-glutamine. Agents Actions 11(3):243-249

Khan S, Bi Bi T (2012) Direct shoot regeneration system for date palm (Phoenix dactylifera L.) cv. Dhakki as a means of micropropagation. Pak J Bot 44:1965-1971

Khierallah HSM, Bader SM (2007) Micropropagation of date palm (Phoenix dactylifera L.) var Maktoom through direct organogenesis. Acta Hortic 736:213-224

Kim YW, Moon HK (2007) Enhancement of somatic embryogenesis and plant regeneration in Japanese larch (Larix leptolepis). Plant Cell Tissue Org Cult 88:241-245

Kim SW, Oh SC, In DS, Liu JR (2003) Plant regeneration of rose (Rosa hybridia) from embryogenic cell-derived protoplasts. Plant Cell Tissue Org Cult 73:15-19

Kiviharju E, Moisander S, Laurila J (2005) Improved green plant regeneration rates from oat anther culture and the agronomic performance of some DH lines. Plant Cell Tissue Organ Cult $81: 1-9$
Kumar N, Gulati A, Bhattacharya A (2013) L-Glutamine and Lglutamic acid facilitate successful Agrobacterium infection of recalcitrant tea cultivars. Appl Biochem Biotechnol 170:1649-1664

Loutfi K, El Hadrami I (2005) Phoenix dactilyfera date palm. In: Litz RE (ed) Biotechnology of fruit and nut crops. CAB International, Wallingford, pp 144-156

Martins JPR, Pasqual M, Martins AD, Ribeira SF (2015) Effects of salts and sucrose concentrations on in vitro propagation of Billbergia zebrina (Herbert) Lindley (Bromeliaceae). Aust J Crop Sci 9:85-91

Mazri MA (2013) Effect of basal medium, explant size and density on the in vitro proliferation and growth of date palm (Phoenix dactylifera L.) cultivar '16-bis'. Not Sci Biol 5:332-337

Mazri MA (2014) Effects of plant growth regulators and carbon source on shoot proliferation and regeneration in date palm (Phoenix dactylifera L.) '16-bis'. J Hortic Sci Biotechnol $89: 415-422$

Mazri MA (2015) Role of cytokinins and physical state of the culture medium to improve in vitro shoot multiplication, rooting and acclimatization of date palm (Phoenix dactylifera L.) $\mathrm{cv}$. Boufeggous. J Plant Biochem Biotechnol 24:268-275

Mazri MA, Meziani R (2013) An improved method for micropropagation and regeneration of date palm (Phoenix dactylifera $\mathrm{L}$.). J Plant Biochem Biotechnol 22(2):176-184

Mazri MA, Meziani R (2015) Micropropagation of date palm: a review. Cell Dev Biol 4(3):160

Meziani R, Jaiti F, Mazri MA, Anjarne M, Ait Chitt M, El Fadile J, Alem C (2015) Effects of plant growth regulators and light intensity on the micropropagation of date palm (Phoenix dactylifera L.) cv. Mejhoul. J Crop Sci Biotechnol 18(5): 325-331

Murashige T, Skoog FA (1962) A revised medium for rapid growth and bioassays with tobacco tissue cultures. Phys Planta $15: 473-479$

Neto VBP, Otoni WC (2003) Carbon sources and their osmotic potential in plant tissue culture: does it matter? Sci Hortic 97:193-202

Newsholme P, Lima MMR, Procopio J, Pithon-Curi TC (2003) Doi SQ, Bazotte RB, Curi R Glutamine and glutamate as vital metabolites. Braz J Med Biol Res 36:153-163

Poothonga S, Reed BM (2014) Modeling the effects of mineral nutrition for improving growth and development of micropropagated red raspberries. Sci Hortic 165:132-141

Reed BM, Wada S, DeNoma J, Niedz RP (2013) Mineral nutrition influences physiological responses of pear in vitro. In Vitro Cell Dev Biol-Plant 49:699-709

Saker MM (2011) Transgenic date palm. In: Jain SM, Al-Khayri JM, Johnson DV (eds) Date palm biotechnology. Springer, Dordrecht, pp 631-650

Sedra MH (2011) Development of new Moroccan selected date palm varieties resistant to bayoud and of good fruit quality. In: Jain SM, Al-Khayri JM, Johnson DV (eds) Date palm biotechnology. Springer, Dordrecht, pp 513-531

Sedra MH (2015) Date Palm Status and Perspective in Morocco. In: Al-Khayri JM, Jain SM, Johnson DV (eds) Date palm genetic resources and utilization. Springer, Dordrecht, pp 257-323

Sepehr MF, Ghorbanli M (2002) Effects of nutritional factors on the formation of Anthraquinones in callus cultures of Rheum ribes. Plant Cell Tissue Org Cult 68:171-175

Taha HS, Bekheet SA, Sakr MM (2001) Factors affecting in vitro multiplication of date palm. Biol Plant 44:431-433

Thorpe T, Stasolla C, Yeung EC, de Klerk GJ, Roberts A, George EF (2008) The components of plant tissue culture media II: organic additions, osmotic and $\mathrm{pH}$ effects, and support systems. In: 
George EF, Hall MA, De Klerk GJ (eds) Plant propagation by tissue culture, 3rd edn. Springer, The Netherlands, pp 115-173

Yaseen M, Ahmad T, Sablok G, Standardi A, Hafiz IA (2013) Review: role of carbon sources for in vitro plant growth and development. Mol Biol Rep 40:2837-2849

Zambom de Souza AZ, Zambom AZ, Abboud KY, Reis SK, Tannihão F, Guadagnini D, Saad MJA, Prada PO (2015) Oral supplementation with L-glutamine alters gut microbiota of obese and overweight human adults: a pilot study. Nutrition 31(6):884-889
Zouine J, El Hadrami I (2007) Effect of 2,4-D, glutamine and BAP on embryogenic suspension culture of date palm (Phoenix dactylifera L.). Sci Hortic 112:221-226

Zouine J, El Bellaj M, Meddich A, Verdeil J, El Hadrami I (2005) Proliferation and germination of somatic embryos from embryogenic suspension cultures in Phoenix dactylifera L. Plant Cell Tissue Org Cult 82:83-92 